\title{
Determinants Affecting Purchase Intention of Organic Food among Medical Employees
}

Fatimah Abd Ghani, Muhammad llyas Mohamad Ajir, Nurfarah Aimi Adli, Noorazlin Ramli, Salmalina Salleh

To Link this Article: http://dx.doi.org/10.6007/IJARBSS/v11-i16/11219

DOI:10.6007/IJARBSS/v11-i16/11219

Received: 04 July 2021, Revised: 30 July 2021, Accepted: 15 August 2021

Published Online: 09 September 2021

In-Text Citation: (Ghani et al., 2021)

To Cite this Article: Ghani, F. A., Ajir, M. I. M., Adli, N. A., Ramli, N., \& Salleh, S. (2021). Determinants Affecting Purchase Intention of Organic Food among Medical Employees. International Journal of Academic

Research in Business and Social Sciences, 11(16), 79-90.

\section{Copyright: (C) 2021 The Author(s)}

Published by Human Resource Management Academic Research Society (www.hrmars.com)

This article is published under the Creative Commons Attribution (CC BY 4.0) license. Anyone may reproduce, distribute, translate and create derivative works of this article (for both commercial and non-commercial purposes), subject to full attribution to the original publication and authors. The full terms of this license may be seen at: http://creativecommons.org/licences/by/4.0/legalcode

Special Issue Title: Contemporary Issues in Tourism and Hospitality industry, 2021, Pg. 79 - 90 


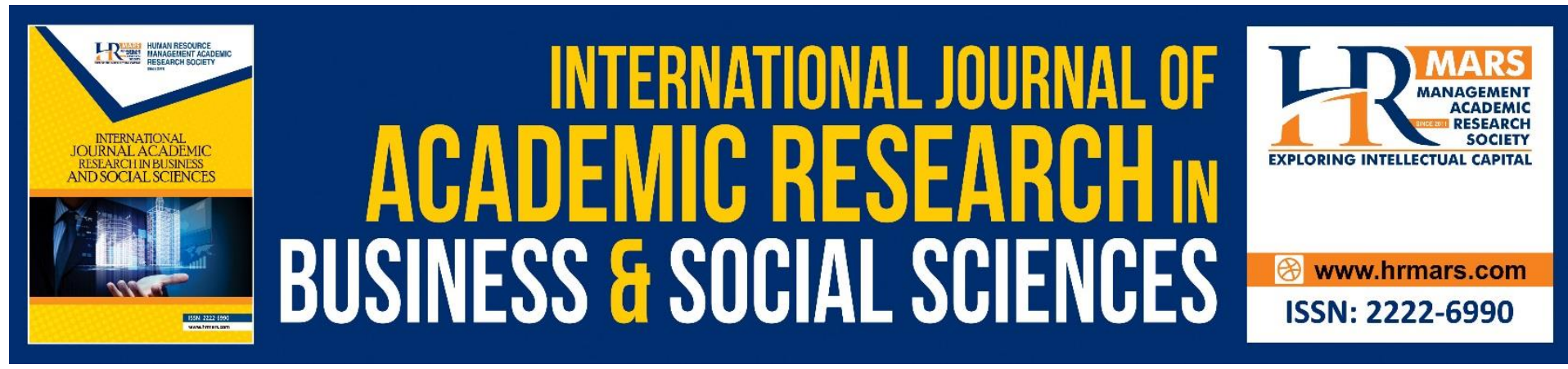

\title{
Determinants Affecting Purchase Intention of Organic Food among Medical Employees
}

\author{
Fatimah Abd Ghani ${ }^{1}$, Muhammad llyas Mohamad Ajir ${ }^{1}$, Nurfarah \\ Aimi Adli ${ }^{1}$, Noorazlin Ramli ${ }^{1}$, Salmalina Salleh² \\ ${ }^{1}$ Faculty of Hotel and Tourism Management, Universiti Teknologi MARA Cawangan \\ Terengganu Kampus Dungun, 23000 Dungun, Terengganu, ${ }^{2}$ Faculty of Social Science and \\ Humanitites, Universiti Teknologi Malaysia, 81310 Skudai, Johor
}

Email: fatim131@uitm.edu.my

\begin{abstract}
Organic food is natural food items restricted from artificial chemicals such as fertilizers, herbicides, pesticides, antibiotics, and genetically modified organisms. Thus, organic food is considered healthy food as synthetic chemicals are prohibited in its production. Organic food has become more common and in greater demand among consumers due to improved awareness of eating healthily. This study aims to identify the determinants that may influence customers' purchase intention of organic food, such as knowledge, safety, health consciousness, environment, price, and availability of the organic food. Moreover, this study discovers the dominant factor that may affect the organic food purchase intention. The participants of this study are the medical employees of Hospital Universiti Sains Malaysia, Kubang Kerian, Kelantan. In finding the factors affecting organic food purchase intention, selfadministered close-ended questionnaires have been distributed to 357 respondents. From the responses, the dominant factors that are affecting organic food purchase intention among the employees are price and availability of organic food. The results of this study may benefit from developing an effective marketing strategy for vendors involved in organic food marketing and help them comprehend their customers' perceptions of organic food.
\end{abstract}

Keywords: Organic Food, Purchase Intention, Consumer's Perceptions, Health Conscious

\section{Introduction}

In many countries such as America, organic foods have become the fastest growing market in the food industries (Somasundram, 2016). In the recent years, the consumption of organic food is increasing in the developed countries such as Europe, North America, and also developing countries like China and India. Consumers worldwide are starting to feel concern in purchasing food based on the nutritious value and food quality (Wang et al., 2018). The majorityity of consumestart to gain concern about on organic food due to the appearance of crisis such pesticide usage in fresh produceces and food contamination with chemical in dairy and fresh food. With the rise of diseases such as obesity, heart attack, and cancer, many consumers begin to select organic food as they believed that organic food is free from the 
usage of chemical. In addition, environmental awareness has also improved people's desire to choose organic food (Mohamad et al., 2014).

In Malaysia, the growth of organic food comes together with the increasing demand from other countries producing organic food and increasing sales. The Malaysian government has started to realize that this industry can gain more profit for the country on the Third National Agriculture Policy (NAP3). Furthermore, it has become a trend to consume organic food among Malaysians due to its nutritional values, consumers' health concern, and the health benefits (Hassan et al., 2015). Nowadays, the trend of purchasing organic food has increased in Malaysia due to the high rate of disease and mindfulness of earth and the environment. Many aspects can affect the purchase intention of organic food from the theories collected from previous literature. This study observes the factors affecting the purchase intention of organic food at an explicit place and explicit consumers as stated above.

\section{Problem in Context}

Food is an important component in human life to ensure they endure in this world. Nowadays, organic food consumption is increasing from the awareness on environmental and health issues related to food consumed by people (Altarawneh, 2013). Consumers have started to realize the importance of quality and safety of food from statistics of increasing consumption lifestyle health issues such as diabetes, heart disease, and cancer caused by the consumption of conventional food (Rana, 2017). Conventional food currently can be found in any market globally with a reasonable price compared to organic food. This is the main reason why majority of consumers choose this product rather than organic food. In fact, Somasundram (2015) stated that the price of organic food is more expensive than conventional food with range of $100 \%$ to $300 \%$ in Malaysia due to the higher production cost.

Moreover, another reason why consumers have started consuming organic food is led by environmental awareness. Based on a statement by Ling (2018), polls are globally increasing in the number of people who have started inducing concern on environmental problems due to some issues arising in the last decades about environmental degradation and the destruction of natural resources. In the recent years, Malaysia has rapidly expanded in agricultural farming and is ranked seventh $\left(7^{\text {th }}\right)$ in the world that imports US 1.7 billion chemical fertilizers. Approximately more than 90 percent $(90 \%)$ of these chemical fertilizers are reported to be applied in numerous forms of agriculture farming in Malaysia. These types of chemical fertilizers, herbicides, and pesticides are used to grow fruits and vegetables. Still, they are considered unsafe for consumers' health because it gives side effects and eventually commits to environmental pollution. Although pesticide is beneficial in agricultural farming in killing living organisms that destroy crops such as weeds, insects, fungus and rodents, the side effects on consumers' health are cancer hormone disruption, asthma, allergies, and hypersensitivity (Kim et al., 2017). Consequently, the main factors causing consumers to choose organic food are the environmental and health awareness related to food. Consumers believe in taking care of the earth from being destroyed by them as well as paving the best way for a healthy life. 


\section{Literature Review \\ Organic Food}

Food free from artificial chemicals such as fertilizers, herbicides, pesticides, antibiotics, and genetically modified organisms is not subjected to irradiation and considered healthy since synthetic chemicals are not used in the production is defined as organic food. Some earlier studies disclosed that many terms that are used to refer to organic food, which are "natural", "local", "fresh", and "pure" (Rana, 2017). González et al (2019) also specified that organic food does not contain any synthetic fertilizers, chemical pesticides, genetically modified organisms (GMOs), hormones, and antibiotics.

In addition, the description of organic food in this research study is provided based on their attributes such as safety, nutrition content, vital qualities, organic integrity, and nature of food. Organic foods are increasing in popularity in both the developed and developing countries. North American and European regions are reported to comprise over $90 \%$ organic foods sales, while several countries in Africa are reported to gain increase in organic farming land from 52,000 hectares in 2000 to 1 million hectares in 2014. Organic food farming growth in African countries is related to the increasing concern of organic food consumption that can improve the quality of life. The purpose initiate for the increasing consumption of organic food in the developing countries is due to increasing awareness of their healthy diet (Rana, 2017).

Consumers' lifestyle, tastes, preferences, standard of living, and purchasing, technical advancement in agriculture and marketing have led to high demand in food manufacturing, convenience food, and health food. Nevertheless, in the developing countries like Malaysia, the market of organic food is still at infant stage due to inadequate information about purchasing organic products by consumers. This research study can help determine the most concerned factor that affects consumers' decision to purchase organic food in Malaysia. By referring to previous researchers', it is found that food consumption patterns among Malaysians differed across three main ethnic groups, which are Malay (approximate 50\%), Chinese (25\%), and Indian (25\%) (Hossain, 2016). In addition, food consumption patterns in Malaysia seem to be growing in a similar pattern with other emerging Asian economies such as Thailand, China, and Republic of Korea. Organic food has a higher importance in global food market and global consumption patterns. Thus, the global production of organic food is anticipated to grow expansively and is also considered as one of the biggest growth markets in food industry in the world (Hossain, 2016).

\section{Purchase Intention of Organic Food}

Meanwhile consumers pay extra attention on environmental problems, the increase of environmental protection events or consumer environmentalism is becoming more prevalent worldwide. Consequently, consumers become more eager to purchase organic products, which are more beneficial to human health and the environment (Ghvanidze et al., 2016; Hsu $\&$ Chen, 2014). Mutiara and Satoshi (2017) defined the purchase intention of organic food as readiness of an individual to implement green buying behaviour that effects less harm or pollution to the environment. Consumers purchase intention towards organic products will increase when people are more sensitive to health and organic consumption, (King et al., 2017). Recently, to support the environment and human health, consumers are keener to purchase fresh and nutritional food with good quality (Laureti \& Benedetti, 2018). 
From earlier study, Vermeir and Verbeke (2008) specified a gap between actual purchasing practices and consumers expressed favourable attitudes. There are small numbers of consumers who really purchased the organic food products even though study showed that many of them have developed positive behaviour towards purchasing the products (Hughner et al., 2007). A research conducted in United Kingdom by Defra (2006) identify that many consumers in the UK have expressed their concern towards the environment, but in fact the consumers rarely convert their concern into actual purchase of green products. Thus, a gap exists between consumers' thinking and actual actions (Wheale \& Hinton, 2007). Therefore, this research is developed to discover the factors that may influence the purchase intention towards organic foods among Hospital Universiti Sains Malaysia employees.

\section{Health Consciousness}

From a study by Bagher (2018), health awareness can be defined as the extent to which people value health in daily activities. When buying food products, consumers usually consider health an important factor and show interest in food and health-related issues. Paul and Rana (2010) stated that consumers who are concerned about their health problems have more intentions to buy organic products. Further, Rennie (2009) states that human health and food safety factors increase consumer interest in organic food compared to conventional food. Nowadays, there are many health problems caused by food intake. Lobb (2007) noted that the health risks posed by food consumption have increased consumer concern for organic food and this is reflected in the growth of the organic food market in recent years in all regions. Consumers are becoming more interested in buying organic products because they do not contain the chemicals used in producing conventional foods (Kushwah et al., 2019).

\section{Methodology}

The medical staff from HUSM Kubang Kerian, Kota Bharu, Kelantan is the analytical study unit. The number of respondents required was determined by the sampling table of Krejcie and Morgan (1970). Based on the table by Krejcie and Morgan, 357 medical officers ( $n=357$ ) were considered sufficient to represent the entire population for this study. Questionnaires for this study were prepared and distributed to the heads of each department at HUSM so that they could help distribute the survey questionnaires to their respective staff. This is done to avoid disruption of medical staff who are busy treating their patients. Furthermore, medical staff from each department at HUSM have different break times as they need to ensure their patients are always attended to. Each respondent was given a pen to complete the questionnaire. The cooperation provided by the respondents has helped to achieve the objectives of this research study. Before the questionnaires was distributed to all respondents, a pilot test was conducted to pre-test the competency of the questionnaire. Each factor of intention to buy organic food was analyzed using SPSS software version 24.0 to check the reliability. Likewise, correlation analysis was used to identify the relationship between factors such as knowledge, safety, health, environment, price, and availability with the intention to purchase organic food among HUSM staff. To ensure that each independent variable correlates with the dependent variable, there is a need to test the variables.

\section{Result and Analysis}

\section{Demographic Profiles}

From 357 respondents who were involved in this research, $68.1 \%(n=243)$ were women. Regarding the age group, 22.4 percent $(n=80)$ respondents were aged between $25-29$ years 
and followed by 18.2 percent $(n=65)$ aged 30 - 34 years. This indicates that there are more medical staff in the age group between 25 to 29 years compared to other age groups. Under the category of the race, the majority of respondents were Malays at 84.9 per cent $(n=303)$. Looking at the level of education, majority of the respondents, 45.7 percent $(n=163)$ are from diploma holders. For the HUSM staff designation, 44.3 percent $(n=158)$ were nurses who responded. Regarding the income level of HUSM staff, (RM), 20.7 percent $(n=74)$ earned between RM1,000 - RM2,000; 41.5 percent ( $n=148$ ) earned between RM2,001- RM3,000; 21.6 percent $(n=77)$ earned between RM3,001- RM4,000; and 16.2 percent $(n=58)$ earning $\mathrm{RM} 4,000$ and above. The frequency of staff who had purchased organic food in the past was also considered important in this study. A large number of customers claimed that they had purchased organic food in the past with 65.8 percent $(n=235)$.

Table 1: Demographic Profile

\begin{tabular}{|l|l|l|}
\hline Variables & Frequency (N) & Percentage (\%) \\
\hline Gender & & \\
Male & 114 & 31.9 \\
Female & 243 & 68.1 \\
Total & 357 & 100.0 \\
\hline Age & & \\
$20-24$ & 49 & 13.7 \\
$25-29$ & 80 & 22.4 \\
$30-34$ & 65 & 18.2 \\
35-39 & 53 & 14.8 \\
$40-44$ & 60 & 16.8 \\
45 and above & 50 & 14.0 \\
Total & 357 & 100.0 \\
& & \\
\hline Race & & \\
Malay & 303 & 84.9 \\
Chinese & 32 & 9.0 \\
Indian & 21 & 5.9 \\
Others & 1 & .3 \\
Total & 357 & 100.0 \\
\hline Education Level & & \\
Diploma & 163 & 45.7 \\
Degree & 74 & 20.7 \\
Master & 12 & 3.4 \\
PHD & 11 & 3.1 \\
Others & 97 & 27.2 \\
Total & 357 & 100.0 \\
\hline Designation & & \\
Doctor & 28 & 4.8 \\
Nurse & 158 & 44.3 \\
Pharmacist & 17 & 43.1 \\
Others & 357 & 100.0 \\
Total & & \\
\hline Income Level & & \\
\hline
\end{tabular}




\begin{tabular}{|l|l|l|}
\hline $1000-2000$ & 74 & 20.7 \\
$2001-3000$ & 148 & 41.5 \\
$3001-4000$ & 77 & 21.6 \\
Above 4000 & 58 & 16.2 \\
Total & 357 & 100.0 \\
\hline Have you purchased organic food before? & & \\
Yes & 235 & 65.8 \\
No & 122 & 34.2 \\
Total & 357 & 100.0 \\
\hline
\end{tabular}

Based on Table 2, the average mean score for consumer knowledge of organic food was served, which was above 4.0. This also meant that the majority of respondents had agreed that 'by having more knowledge, this would help my purchasing decision' had the highest mean $(M=4.60)$, followed by 'I know that organic foods are safe to eat' $(M=4.59)$. Then, 'I want to learn more about organic food' $(M=4.52)$ and lastly, the lowest mean for this section was 'I know several types of organic food on the market' $(M=4.40)$.

Table 2: The Overall Mean Score of Consumer Knowledge on Organic Food

\begin{tabular}{|c|c|c|c|c|c|}
\hline $\begin{array}{ll}\text { SECTION } & \text { B: } \\
\text { CONSUMER'S } & \\
\text { KNOWLEDGE } & \text { ON } \\
\text { ORGANIC FOODS } & \end{array}$ & $\mathbf{N}$ & Minimum & Maximum & Mean & $\begin{array}{l}\text { Standard } \\
\text { Deviation }\end{array}$ \\
\hline $\begin{array}{l}\text { CKOF: Having more } \\
\text { knowledge }\end{array}$ & 357 & 3 & 5 & 4.60 & .513 \\
\hline $\begin{array}{l}\text { CKOF: Would like to } \\
\text { learn }\end{array}$ & 357 & 1 & 5 & 4.52 & .573 \\
\hline CKOF: Safe to consume & 357 & 2 & 5 & 4.59 & .557 \\
\hline $\begin{array}{l}\text { CKOF: Several type of } \\
\text { organic food }\end{array}$ & 357 & 3 & 5 & 4.40 & .640 \\
\hline
\end{tabular}

Referring to Table 3 below, the majority of respondents have stated that 'organic food is safer to eat' $(M=4.57)$. This was followed by 'organic foods were free of chemicals and organic foods did not contain genetically modified substances' $(M=4.52)$. The mean value $(M=4.47)$ possessed by 'organic food can reduce the risk of food poisoning'. These results indicate that the average mean score for all items under organic food safety is more than 4.00 which tends to be acceptable. 
Table 3: The Overall Mean Score on Safety of Organic Foods

\begin{tabular}{|l|l|l|l|l|l|}
\hline $\begin{array}{l}\text { SECTION C: SAFETY OF } \\
\text { ORGANIC FOODS }\end{array}$ & N & Minimum & Maximum & Mean & $\begin{array}{l}\text { Standard } \\
\text { Deviation }\end{array}$ \\
\hline SOF: Safer to eat & 357 & 3 & 5 & 4.57 & .539 \\
\hline $\begin{array}{l}\text { SOF: Free from } \\
\text { chemical }\end{array}$ & 357 & 2 & 5 & 4.52 & .593 \\
\hline $\begin{array}{l}\text { SOF: Genetically } \\
\text { modified }\end{array}$ & 357 & 3 & 5 & 4.52 & .583 \\
\hline SOF: Food poisoning & 357 & 1 & 5 & 4.47 & .672 \\
\hline
\end{tabular}

Referring to Table 4, the highest average mean score was organic food more nutritious than conventional food $(M=4.50)$, indicating that consumers believed that organic food had more convection food nutrients based on their knowledge. Next, 'I choose foods carefully for good health safety and I often face health-related problems' obtained a mean score similar to 4.37. Then, the lowest mean score for health awareness of organic foods was 'I often consume processed foods' ( $M=3.98)$, this is because a number of respondents sometimes consume processed foods in their diet.

Table 4: The Overall Mean Score on Health Consciousness on Organic Food

\begin{tabular}{|l|l|l|l|l|l|}
\hline $\begin{array}{l}\text { SECTION D: HEALTH } \\
\text { CONSCIOUSNESS ON } \\
\text { ORGANIC FOODS }\end{array}$ & N & Minimum & Maximum & Mean & $\begin{array}{l}\text { Standard } \\
\text { Deviation }\end{array}$ \\
\hline HCOF: Choose carefully & 357 & 3 & 5 & 4.37 & .647 \\
\hline $\begin{array}{l}\text { HCOF: Health-related } \\
\text { issue }\end{array}$ & 357 & 2 & 5 & 4.37 & .681 \\
\hline HCOF: Processed food & 357 & 1 & 5 & 3.98 & .945 \\
\hline HCOF: More nutritious & 357 & 3 & 5 & 4.50 & .574 \\
\hline
\end{tabular}

Referring to Table 5, most respondents gave a higher score because the use of chemical fertilizers will affect the environment with a mean score, $M=4.68$. On the other hand, the use of pesticides will affect the environment and organic farming is good because the environment has the same mean score $(M=4.65)$. The lowest average in this section is that the use of herbicides will affect the environment $(M=4.61)$. 
Table 5: The Overall Mean Score on Environment of Organic Food

\begin{tabular}{|l|l|l|l|l|l|}
\hline $\begin{array}{l}\text { SECTION E: } \\
\text { ENVIRONMENT OF } \\
\text { ORGANIC FOODS }\end{array}$ & Minimum & Maximum & Mean & $\begin{array}{l}\text { Standard } \\
\text { Deviation }\end{array}$ \\
\hline EOF: Organic farming & 357 & 2 & 5 & 4.65 & .532 \\
\hline EOF: Chemical fertilizer & 357 & 3 & 5 & 4.68 & .512 \\
\hline EOF: Pesticide & 357 & 3 & 5 & 4.65 & .505 \\
\hline EOF: Herbicide & 357 & 3 & 5 & 4.61 & .528 \\
\hline
\end{tabular}

From the results obtained in Table 6, the majority of respondents agreed that they choose organic food if the organic food is available in the market $(M=4.45)$. The second mean score of consumers who were willing to buy organic food, while their choice was limited ( $M=4.42$ ). The third mean score are consumers who bought organic food regardless of its price $(M=$ 4.32) and the lowest mean score were consumers who would still buy organic food even though conventional food are on sale ( $M=4.17)$.

Table 6: The Overall Mean Score on Price and Availability of Organic Foods

\begin{tabular}{|l|l|l|l|l|l|}
\hline $\begin{array}{l}\text { SECTION F: PRICE AND } \\
\text { AVAILABILITY OF } \\
\text { ORGANIC FOODS }\end{array}$ & Minimum & Maximum & Mean & $\begin{array}{l}\text { Standard } \\
\text { Deviation }\end{array}$ \\
\hline $\begin{array}{l}\text { PAOF: Willing to } \\
\text { purchase }\end{array}$ & 357 & 2 & 5 & 4.32 & .746 \\
\hline $\begin{array}{l}\text { PAOF: Conventional } \\
\text { food on sale }\end{array}$ & 357 & 2 & 5 & 4.17 & .795 \\
\hline $\begin{array}{l}\text { PAOF: Available in } \\
\text { market }\end{array}$ & 357 & 3 & 5 & 4.45 & .591 \\
\hline PAOF: Limited choices & 357 & 3 & 5 & 4.42 & .593 \\
\hline
\end{tabular}

Looking at the scores tabulated below in Table 7, most respondents explicitly agreed that the least mean purchase intention of organic food is 'I have the intention to buy organic food on a regular basis with a mean score $(M=4.33)$ This is then followed by 'I have the intention to buy organic food despite lack of knowledge', $(M=4.35)$ and 'I intend to recommend others to buy organic food', ( $M=4.39)$. The highest mean score in this section was 'I have the intention to buy organic food when I have the knowledge' with a mean score, $(M=4.48)$. 
Table 7: The Overall Mean Score on Purchase Intention of Organic Foods

\begin{tabular}{|l|l|l|l|l|l|}
\hline $\begin{array}{l}\text { SECTION G: PURCHASE } \\
\text { INTENTION OF } \\
\text { ORGANIC FOODS }\end{array}$ & Minimum & Maximum & Mean & $\begin{array}{l}\text { Standard } \\
\text { Deviation }\end{array}$ \\
\hline $\begin{array}{l}\text { PIOF: Have the } \\
\text { knowledge }\end{array}$ & 357 & 2 & 5 & 4.48 & .630 \\
\hline $\begin{array}{l}\text { PIOF: Lack of } \\
\text { knowledge }\end{array}$ & 357 & 2 & 5 & 4.35 & .669 \\
\hline PIOF: Regular basis & 357 & 3 & 5 & 4.33 & .629 \\
\hline $\begin{array}{l}\text { PIOF: Recommend } \\
\text { others }\end{array}$ & 357 & 2 & 5 & 4.39 & .579 \\
\hline
\end{tabular}

Based on Table 8, the price and availability are the strong factor that affects the intention to purchase organic food in HUSM (0.691). This is followed by safety of the organic food $(0.600)$; consumer knowledge of organic food (0.580); health consciousness on organic food (0.484). For the low rate of Pearson Correlation is environment of organic food (0.433). By referring to the results below, the dominant factors that influence customers' purchase intention on organic food have been determined. The dominant factors of this research study are price and availability hence from the result analysis, both (0.691) in a strong scale according to the Pearson Correlation.

Table 8: Pearson Correlation

\begin{tabular}{|l|l|l|l|l|l|}
\hline Correlation & Knowledge & Safety & health & environment & price \\
\hline $\begin{array}{l}\text { Intention to purchase } \\
\text { organic food (DV) }\end{array}$ & $.580^{* *}$ & $.600^{* *}$ & $.484^{* *}$ & $.433^{* *}$ & $.691^{* *}$ \\
\cline { 2 - 6 } & .000 & .000 & .000 & .000 & .000 \\
\cline { 2 - 6 } & 357 & 357 & 357 & 357 & 357 \\
\hline
\end{tabular}

\section{Conclusion}

The results of this study clearly indicate that the price and availability of organic food are the dominant factors influencing customers to buy organic food and followed by knowledge about organic food. When the prices of organic products are affordable and do not have a high comparison with conventional foods, many consumers will choose organic foods because of their health benefits and higher nutritional value than conventional foods. The purpose of buying organic food will also increase if the product is easily accessible in any store and market. With this information, organic product retailers and the government should be aware and take action on how to make organic products comparable to conventional products.

Knowledge of organic food becomes the second dominant factor influencing customers to buy organic products. The results showed that knowledge had a significant positive effect on the intention to buy organic food. People who know more about organic food will contribute more to buying organic products because they know its benefits. Therefore, retailers should make 
them their target market and position themselves as providers of high-quality products. This strategy will help them attract consumers who are willing to pay more for better quality and healthier products.

In conclusion, the objective of this study is to identify the determinants that can influence customers 'organic food purchase intentions and to determine the dominant factors that can influence customers' purchase intentions towards organic food. The determinants of this study, namely knowledge, safety, health awareness, environment, price, and availability, had a significant relationship with intention to purchase organic food. Therefore, it can be concluded that Malaysians are more concerned about the environment and their health. From the results of the study, it was found that the dominant factors influencing customers 'buying intentions towards organic food were price and availability. Price and availability are the main reasons influencing customers 'buying intentions towards organic food. If the government controls the price of organic food and is offered in any store, the intention to buy organic products will increase.

\section{Corresponding Author}

Fatimah Abd Ghani. Faculty of Hotel and Tourism Management, Universiti Teknologi MARA Cawangan Terengganu Kampus Dungun.

E-mail: fatim131@uitm.edu.my

\section{References}

Altarawneh, M. (2013) Consumer Awareness towards Organic Food: A Pilot Study in Jordan. J. Agric. Food. Tech., 3(12)14-18, 2013

Bagher, A. N. (2018). Factors Affecting Intention to Purchase Organic Food Products Among Iranian Consumers. Academy of Marketing Studies Journal, 22(3).

Defra. (2006). Department for Environment, Food and Rural Affairs and the Forestry Sustainable Consumption and Production: Encouraging Sustainable Consumption. Retrieved from: archive.defra.gov.uk/corporate/about reports/documents/ 2006deptreport.pdf

Ghvanidze, S., Velikova, N., Dodd, T. H., \& Wilna, O. T. (2016). Consumers' Environmental and Ethical Consciousness and The Use of The Related Food Products Information: The Role of Perceived Consumer Effectiveness. Appetite, 107, 311-322. https://doi.org/10.1016/j.appet.2016.08.097.

González, N., Marquès, M., Nadal, M., José, L., \& Domingo. (2019). Occurrence of Environmental Pollutants in Foodstuffs: A Review of Organic Vs. Conventional Food. Food and Chemical Toxicology 125 (2019) 370-375

Hassan, S. H., Yee, L. W., Ray, K. J. (2015) Purchasing Intention Towards Organic Food Among Generation Y In Malaysia. Journal of Applied Sciences, 15(3): 570-575, 2015.

Hossain, M. T., Lim, P. X. (2016). Consumers' Buying Behavior Towards Organic Foods. Malaysian Management Review, 51, 7-26.

Katt, F., \& Meixner, O. (2020). Is it all about the price? An analysis of the purchase intention for organic food in a discount setting by means of structural equation modeling. Foods, 9(4), 458.

Hsu, S. Y., Chang, C. C., Lin, T. T. (2016). An Analysis of Purchase Intentions Toward Organic Food on Health Consciousness and Food Safety With/Under Structural Equation Modelling. Br. Food J. 118 (1), $200 \mathrm{e} 216$. 
Hsu, C. L., \& Chen, M. C. (2014). Explaining Consumer Attitudes and Purchase Intentions Toward Organic Food: Contributions from Regulatory Fit and Consumer Characteristics. Food Quality and Preference, 35, 6-13. https://doi.org/10.1016/j.foodqual.2014.01. 005.

Hughner, R., Mcdonagh, P., Prothero, A., Shultz, J., Stanton, J. (2007). Who Are Organic Food Consumers? A Compilation and Review of Why People Purchase Organic Food. J. Consum. Behav. 6 (2/3), 94e110.

Kim, K. H., Kabir, E., Jahan, S. A. (2017) Exposure to pesticides and the associated human health effects. Science of the Total Environment, 575, 525-535. http://dx.doi.org/10.1016/j.scitotenv.2016.09.009

Krejcie, R. V., Morgan, D. W. (1970). Determining Sample Size for Research Activities. Educational And Psychological Measurement, 30, 607-610.

Kushwah, S., Dhir, A., Sagar, M. (2019). Understanding consumer resistance to the consumption of organic food: A study of ethical purchasing, consumption and purchase behaviour. Food Quality and Preference, 1-1

Laureti, T., \& Benedetti, I. (2018). Exploring Pro-Environmental Food Purchasing Behaviour: An Empirical Analysis of Italian Consumers. Journal of Cleaner Production, 172, 3367-3378. https://doi.org/10.1016/j.jclepro.2017.11.086.

Ling, T. P., Dominic, F. L., Shanmugam, A. (2018). The Purchase Intention of Organic Foods Among Working Adults in Penang, Malaysia. South East Asia Journal of Contemporary Business, Economics and Law, 17(2), 2289-1560.

Mohamad, S. S., Rusdi, S. D., \& Hashim, N. H. (2014). Organic Food Consumption among Urban Consumers: Preliminary Results. Procedia - Social and Behavioral Sciences, 130, 509-514.

Mutiara, V. I., \& Satoshi, A. (2017). The Challenges in Organic Agricultural Products Market in Southeast Asia. Reviews in Agricultural Science, 5, 36-44. https://doi.org/10.7831/ras.5.36.

Paul, J., Rana, J. (2017). Consumer behavior and purchase intention for organic food. Journal of Retailing and Consumer Services, 157-165.

Rennie, F. A. (2009). Consumer Perceptions towards Organic Food. Elsevier.

Somasundram, C., Razali, Z., Santhirasegaram, V. (2016) A Review on Organic Food Production in Malaysia. Horticulturae, 2, 12.

Vermeir, I., Verbeke, W. (2008). Sustainable Food Consumption: Exploring the Consumer Attitude-behaviour Gap. Working Paper No. 121. Ghen University, Belgium, pp. 65e78.

Wang, X., Pacho, F., Liu, J., \& Kajungiro, R. (2019). Factors influencing organic food purchase intention in developing countries and the moderating role of knowledge. Sustainability, 11(209), 1-18.

Wheale, P., Hinton, D. (2007). Ethical Consumers in Search of Markets. Bus. Strategy Environment. 16 (4), 302e315. 